\title{
UJ SENSITIVITAS ANTIBIOTIK TERHADAP BAKTERI PENYEBAB INFEKSI SALURAN KEMIH PADA PASIEN RAWAT INAP DI RSUD PROF. DR MARGONO SOEKARJO PURWOKERTO
}

\section{ANTIBIOTIC SENSITIVITY OF URINARY TRACT INFECTION BACTERIA ON INPATIENT OF PROF. DR. MARGONO SOEKARJO HOSPITAL AT PURWOKERTO}

\author{
Adzkie Muhammad, Nunuk Aries Nurulita, Arif Budiman \\ Fakultas FarmasiUniversitas Muhammadiyah Purwokerto \\ Jl. Raya Dukuhwaluh, PO Box 202, Kembaran, Banyumas 53183, Indonesia \\ Email: nunuknurulita@yahoo.com (Nunuk Aries Nurulita)
}

\begin{abstract}
ABSTRAK
Penyakit infeksi masih merupakan penyebab kesakitan dan kematian yang tinggi di seluruh dunia, khususnya di negara berkembang seperti Indonesia. Di antara bakteri patogen, Escherichia coli merupakan bakteri paling umum menjadi penyebab infeksi saluran kemih pada pasien rawat jalan maupun rawat inap. Tujuan dari penelitian ini adalah mengidentifikasi jenis bakteri penyebab serta pola bakteri dan tingkat sensitivitas antibiotik terhadap bakteri penyebab infeksi saluran kemih (ISK) pada pasien rawat inap di RSUD Prof. Dr. Margono Soekarjo Purwokerto. Penelitian ini menggunakan dua jenis antibiotik yaitu asam pipemidat dan cefixime. Uji yang dilakukan meliputi uji hemosis, identifikasi bakteri secara biokimia, dan uji sensitivitas antibotik dengan metode difusi agar. Hasil uji identifikasi biokimia menunjukkan bahwa uji indol dan methyl red positif sedangkan uji Voges Proskauer (VP) dan sitrat hasilnya negatif. E. coli menurut Bergey manual menunjukkan hasil positif untuk uji indol dan methyl red sedangkan uji VP dan sitrat negatif. Diduga bakteri penyebab ISK pada penelitian ini adalah E. coli. Hasil uji sensitivitas bakteri terhadap antibiotik menunjukkan bahwa bakteri masih sensitif terhadap asam pipemidat sebesar $66,7 \%$ dan intermediet $33,3 \%$. Antibiotik cefixime sebesar sensitif $55,6 \%$ dan intermediet $44,4 \%$. Kedua antibiotik tersebut masih efektif digunakan untuk mengatasi ISK.
\end{abstract}

Kata kunci: infeksi saluran kemih (ISK), sensitivitas, antibiotik, rawat inap.

\section{ABSTRACT}

Infectious diseases cause high morbidity and mortality at worldwide, especially in developing countries like Indonesia. Among pathogenic bacteria, Escherichia coli is the common bacteria caused urinary tract infections (UTI) either on an out- or inpatient. The purpose of this study is identify the type of bacteria isolated from UTI patient at Prof. Dr Margono Soekarjo Purwokerto hospital. This research also determined the sensitivity levels of isolated bacteria against two type antibiotics, pipemidat acid and cefixime. The bacterial identification was conducted using hemosis assay, biochemical assay, and 
antibiotics sensitivity assay using agarose diffusion method. The results showed that the biochemical identification of indole and methyl red test was positive while VP and citrate test results were negative. According to Bergey's manual shows that $E$. coli resulted the positive results of indole and methyl red test, while sirat and VP test negative. Suspected bacteria that cause UTI in this study was E. coli. The test results demonstrate the sensitivity of bacteria to antibiotics that the bacteria remain sensitive to acid pipemidat by $66.7 \%$ and $33.3 \%$ intermediates. Antibiotic cefixime amounted to $55.6 \%$ sensitive and 44.4\% intermediates. Both of antibitics are still effective for UTI treatment.

Key words: urinary tract infection (UTI), antibiotic, sensitivity, hospitalization. 


\section{Pendahuluan}

Penyakit infeksi masih merupakan penyebab kesakitan dan kematian yang tinggi di seluruh dunia, khususnya di negara berkembang seperti Indonesia (Guntur dan Sepsis, 2007). Penyakit Infeksi Saluran Kemih (ISK) merupakan masalah kesehatan masyarakat di Indonesia yang perlu mendapatkan perhatian yang serius. ISK adalah salah satu penyakit infeksi yang sering terjadi di Indonesia. ISK dapat mengenai baik laki-laki maupun perempuan dari semua umur baik pada anak, remaja, dewasa, maupun umur lanjut (Tessy et al., 2004).

Data penelitian epidemologi klinik melaporkan 25-35\% perempuan dewasa pernah mengalami ISK. Perempuan umumnya empat sampai lima kali lebih rentan terinfeksi ISK dibandingkan pria (Sotelo dan Westney, 2003).

ISK dinyatakan apabila ditemukan bakteri di dalam urin. Mikroorganisme yang paling sering menyebabkan ISK adalah jenis aerob. Pada saluran kemih yang normal tidak dihuni oleh bakteri aerob atau mikroba yang lain, karena itu urin dalam ginjal dan buli- buli biasanya steril. Walaupun demikian uretra bagian bawah terutama pada wanita dapat dihuni oleh bakteri yang jumlahnya makin kurang pada bagian yang mendekati kandung kemih. Escherichia coli menduduki persentasi biakan paling tinggi yaitu sekitar 5090\% (Kumala et al., 2009).

Bakteri patogen penyebab ISK seringkali dapat diperkirakan, dan Escherichia coli merupakan bakteri patogen utama baik pada pasien rawat jalan maupun rawat inap (Sahm et al., 2001). Staphylococcus saprophyticus, Klebsiella spp., Proteus spp., Enterococcus spp., dan Enterobacter spp merupakan patogen lain yang menjadi penyebab infeksi saluran kemih, namun jarang ditemukan (Sahm et al., 2001).

Kumala et al.

(2009) menyebutkan beberapa antibiotik telah resisten terhadap bakteri penyebab ISK. Pengujian kepekaan bakteri yang ada dalam urin mempunyai peranan penting karena pada pasien penderita ISK yang menggunakan antibiotik untuk jangka panjang dapat memacu terjadinya resistensi terhadap bakteri.

Penggunaan antibiotik adalah pilihan utama dalam pengobatan ISK. Pemakaian antibiotik secara efektif dan optimal memerlukan pengertian dan pemahaman mengenai bagaimana memilih dan memakai antibiotik secara 
benar. Pemilihan berdasarkan indikasi yang tepat, menentukan dosis, cara pemberian, lama pemberian, maupun evaluasi efek antibiotik. Pemakaian dalam klinik yang menyimpang dari prinsip dan pemakaian antibiotik secara rasional akan membawa dampak negatif dalam bentuk meningkatnya resistensi, efek samping, dan pemborosan.

\section{Metode Penelitian}

\section{Alat dan Bahan}

Alat yang digunakan dalam penelitian yaitu: Laminar Air Flow (Biotek), Autoklaf (ALP), dan inkubator (Incucell). Bahan-bahan yang digunakan pada penelitian ini yaitu sampel berupa urin, Nutrient Agar (NA), agar Mueller Hinton, cakram, antibiotik cefotaxim dan cefriaxon media Mac Conkey Agar (MCA), Media Methyl Red-Voges Proskauer (MR-VP), media Simon Citrat Agar (SCA), reagen pewarna Gram (larutan gentian violet, lugol, alkohol 95\%, safranin), akuades, $\mathrm{H}_{2} \mathrm{O}_{2} 3 \%$.

\section{Jalannya Penelitian}

1. Pengambilan sampel urin

Adapun cara pengambilan sampel urin segar yaitu wadah urin yang steril dan kering untuk menampung urin disediakan. Wadah urin harus steril agar tidak ada bakteri lain yang mengkontaminasi sampel urin yang telah didapat. Urin yang pertama kali keluar dibuang, kemudian aliran urin selanjutnya ditampung dalam wadah yang sudah disediakan dan wadah yang sudah berisi urin ditutup rapat dan segera dibawa ke laboratorium untuk segera diperiksa.

2. Pembuatan medium

NA sebanyak 8 gram dilarutkan dalam $400 \mathrm{~mL}$ akuades. Kemudian bahan agar dipanaskan di dalam Erlenmeyer sampai media terlarut sempurna. Media disterilisasi menggunakkan autoklaf pada tekanan 1 atm dan suhu $121{ }^{\circ} \mathrm{C}$ selama \pm 15 menit. Setelah media dingin sampai teraba hangat-hangat kuku, ditambahkan darah domba sebanyak $17 \mathrm{~mL}$ ke dalam Erlenmeyer. Kemudian media dituangkan ke dalam cawan petri steril dan dibiarkan membeku.

3. Penanaman dan pembiakan

Sampel urin penderita infeksi saluran kemih dari wadah steril tadi diambil ose steril, kemudian ose steril dicelupkan ke dalam urin kemudian diusapkan ke dalam media 
Blood Agar atau media McConkey

untuk proses penanaman dan pembiakan. Media tersebut diinkubasi pada suhu $37{ }^{\circ} \mathrm{C}$ selama 24 jam, untuk lebih lengkapnya dilanjutkan dengan prosedur identifikasi bakteri penelitian.

4. Inokulasi bakteri ke medium nutrient agar (NA)

NA sebanyak 8 gram dilarutkan dalam 400 mL akuades. Kemudian bahan agar dipanaskan di dalam Erlenmeyer sampai media terlarut sempurna. Media disterilisasi menggunakkan autoklaf pada tekanan 1 atm dan suhu $121{ }^{\circ} \mathrm{C}$ selama \pm 15 menit. Setelah media dingin sampai teraba hangathangat kuku, ditambahkan darah domba sebanyak $17 \mathrm{~mL}$ ke dalam Erlenmeyer. Kemudian media dituangkan ke dalam cawan petri steril dan dibiarkan membeku.

Biakan diambil dari media Blood Agar atau media Mac Conkey, lalu diinokulasikan ke dalam medium NA dengan menggunakan ose lurus secara aseptis, kemudian diinkubasi selama $1 \times 24$ jam pada suhu $37{ }^{\circ} \mathrm{C}$.

5. Identifikasi bakteri

a. Pewarnaan gram
Isolat bakteri dari ke-9 sampel dari media agar darah diambil 1 ose dan digores-goreskan pada permukaan preparat steril kemudian dilakukan fiksasi. Kristal violet sebanyak 1 tetes ditambahkan ke permukaan preparat yang terdapat lapisan bakteri tersebut dan didiamkan selama 1 menit. Setelah 1 menit, preparat dibilas dengan air sampai zat warna luntur. Preparat dikeringkan di atas api spiritus. Setelah kering, larutan iod sebanyak 1 tetes ditambahkan ke permukaan preparat tersebut dan didiamkan selama 1 menit. Setelah 1 menit, preparat dibilas dengan air. Preparat dibilas dengan alkohol $96 \%$ sampai semua zat warna luntur kemudian dicuci dengan air. Preparat dikeringkan di atas api spiritus. Setelah kering, safranin sebanyak 1 tetes ditambahkan ke permukaan preparat dan didiamkan selama 45 detik. Preparat dicuci dengan air dan dikeringkan. Preparat diamati menggunakan mikroskop dengan perbesaran 1000x.

b. Uji indol 
Biakan NA miring ditanam 1 sengkelit, dibiakan ke dalam tryptone broth. Diinkubasi selama 24 jam dengan suhu $37 \stackrel{\circ}{ } \mathrm{C}$, ditambahkan 0,2-0,3 mL pereaksi indol ke dalam masing-masing tabung, kocok dan didiamkan selama beberapa menit. Warna merah cherry pada permukaan membentuk cincin menandakan reaksi indol positif, warna jingga menunjukkan reaksi indol negatif.

c. Uji methyl red

Biakan NA miring ditanam 1 sengkelit biakan ke dalam pembenihan MR-VP. Biakan diinkubasi selama 24 jam dengan suhu 37 으, setelah diinkubasi ditambahkan 5 tetes methyl red, dikocok, dan didiamkan selama beberapa menit. Warna kuning menunjukkan reaksi negatif dan warna merah menunjukkan reaksi positif.

d. Uji VP (Voges Proskauer)

Biakan NA miring ditanam 1 sengkelit biakan ke dalam pembenihan MR-VP. Biakan diinkubasi selama 24 jam dengan suhu 37 으. Setelah diinkubasi, ditambahkan 3 tetes larutan alfa naftol dan 2 tetes larutan $\mathrm{KOH}$
40\%, dikocok, dan didiamkan selama beberapa menit. Warna merah muda sampai merah tua menunjukkan hasil positif, dan jika tidak berubah warna maka menunjukkan hasil negatif.

e. Uji sitrat

$$
\text { Biakan NA miring ditanam } 1
$$
sengkelit biakan ke dalam pembenihan Simmons citrat, lalu diinkubasi selama 24 jam dengan suhu 37 oC. Warna biru menunjukkan hasil positif, warna hijau menunjukkan hasil negatif (Irianto, 2006).

6. Uji kepekaan antibiotik

Pembuatan suspensi bakteri yaitu dengan cara mengambil satu ose bakteri dari media NA yang telah diinkubasi selama 24 jam, dimasukkan ke dalam tabung yang berisi $\mathrm{NaCl}$ fisiologis sebanyak $10 \mathrm{~mL}$ kemudian dihomogenkan. Densitas optik diukur pada panjang gelombang $600 \mathrm{~nm}$. Nilai absorbansi yang dihasilkan kemudian dikonversi menjadi 0,1. Densitas optik 0,1 senilai dengan nilai standar McFarland (kepadatan sel bakteri $1 \times 10^{8} \mathrm{sel} / \mathrm{mL}$ ) kemudian suspensi bakteri uji yang telah dibuat dilakukan pengenceran secara 
berseri untuk mendapatkan kepadatan $10^{6} \mathrm{CFU} / \mathrm{mL}$.

Uji sensitivitas bakteri dilakukan dengan cara sebagai berikut: agar Mueller Hinton sebanyak $20 \mathrm{~mL}$ dipipet ke dalam cawan petri, dibiarkan menjadi padat. Suspensi bakteri lalu dipindahkan secara aseptik dengan menggunakan mikro pipet ke atas permukaan agar Mueller Hinton, kemudian diratakan suspensi bakteri, dibiarkan beberapa menit. Setelah itu masing-masing disk antibiotik diletakkan di atasnya dan diinkubasi pada suhu $37 \stackrel{\circ}{\mathrm{C}}$ selama 24 jam. Ulangan dilakukan sebanyak tiga kali pada petri yang berbeda. Setelah inkubasi, diamati adanya diameter zona hambatan pertumbuhan bakteri di luar cakram tersebut. Koloni bakteri yang sensitif terhadap antibiotik dilihat dengan adanya zona hambatan berupa daerah bening di sekitar cakram antibiotik.
7. Analisis data

Data yang diperoleh berupa zona hambat dari masing-masing antibiotik yang kemudian diolah secara deskriptif untuk mengetahui pola bakteri dan sensitivitas antibiotik terhadap bakteri penyebab infeksi saluran kemih di RSUD Prof. Dr. Margono Soekarjo.

\section{Hasil dan Pembahasan}

Uji Hemolisis

Karakteristik hemolisis yang diidentifikasi dari urin penderita ISK sebanyak 27 isolat bakteri, yang diduga sebagai beta ( $\beta$ ) sebanyak 27 isolat bakteri. Hasil penelitian ini menunjukkan bahwa semua isolat bakteri uji hemolisis diketahui memiliki kemampuan beta $(\beta)$ hemolisis, yaitu dapat melisiskan sel-sel darah merah secara sempurna. Hal ini ditunjukkan pada Gambar 1.

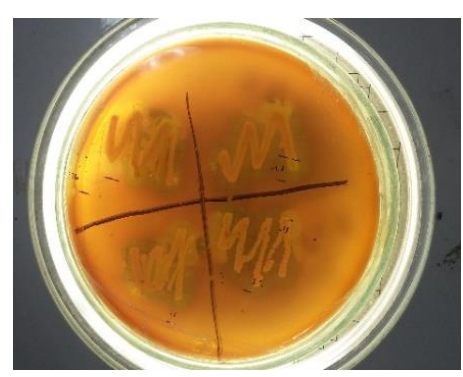

Gambar 1. Hasil uji hemolisis pada sampel urin penderita ISK. 
Uji Identifikasi Bakteri

1. Pewarnaan Gram

Hasil uji pengecetan Gram pada penelitian ini dapat dilihat pada Gambar 2 yang menunjukkan bahwa semua sampel hasil pengecetan berwarna merah dilihat pada mikroskop perbesaran 100x. Bakteri
E. coli merupakan bakteri Gram negatif berbentuk batang yang termasuk dalam famili Enterobacteriaceae. Baktei ini merupakan penghuni normal usus, selain berkembang biak di lingkungan sekitar manusia (Arisman, 2009).
A

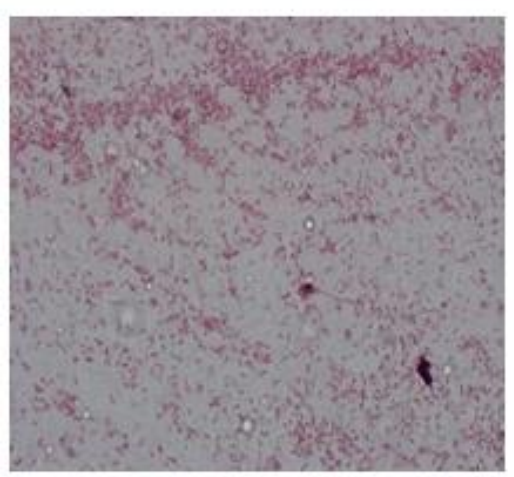

B

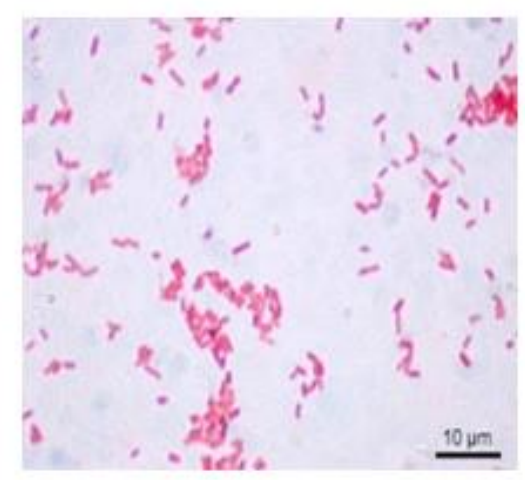

Gambar 2. Gambar A menunjukkan hasil pengecetan pewarnaan Gram pada sampel urin pasien ISK, sedangkan gambar B menunjukkan pewarnaan Gram negatif berdasar literatur.

Pada studi penelitian Seta et al. (2015), bakteri penyebab ISK adalah E. coli, Klebsiella pneumonia, Staphylococus aureus, Proteus mirabilis, Enterococcus faecalis, dan Enterobacter aerogenes. Pada penelitian Sumolang et al. (2013) bakteri penyebab ISK yang terbesar adalah E. coli. Hasil identifikasi dari urin penderita ISK pada penelitian ini diduga yaitu $E$. coli.
2. Uji indol

Pada penelitian ini dari 27 isolat bakteri, terdapat 27 isolat bakteri positif uji indol. E. coli mempunyai tipe metabolisme fermentasi dan respirasi tetapi pertumbuhannya paling sedikit banyak di bawah keadaan anaerob pertumbuhan yang baik pada suhu optimal $37^{\circ} \mathrm{C}$ pada media yang mengandung $1 \%$ pepton sebagai sumber karbon dan 
nitrogen. E. coli memfermentasikan laktosa dan memproduksi indol yang digunakan untuk mengidentifikasi bakteri pada makanan dan air. E. coli menghasilkan enzim triptofanase yang mengkatalisasikan penguraian gugus indol dari triptofan. Dalam media biakan, indol menumpuk sebagai produk buangan, sedangkan bagian lainnya dari molekul triptofan (asam piruvat dan $\mathrm{NH}_{4}^{+}$) dapat digunakan untuk memenuhi kebutuhan zat hara mikroorganisme. Pereaksi bereaksi dengan indol dan menghasilkan senyawa yang tidak larut dalam air dan berwarna merah pada permukaan medium. Hasil penelitian uji indol dapat dilihat pada Gambar 3 yang menunjukkan terbentuknya cincin merah.

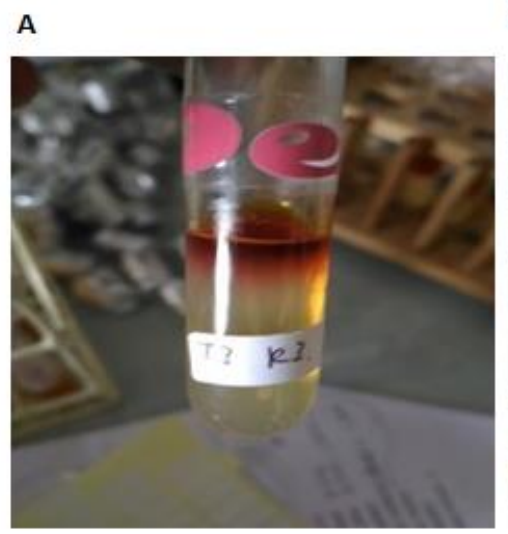

B

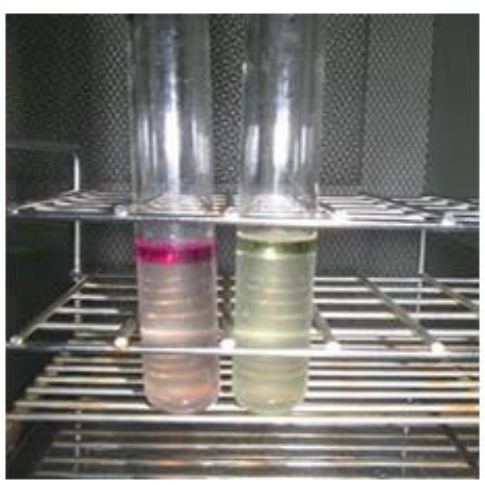

Gambar 3. Gambar A menunjukkan hasil positif pada uji Indol sampel urin pada pasien ISK, sedangkan gambar B hasil uji indol jika bewarna merah (+) dan tidak berwarna (-).

3. Uji methyl red

Pada penelitian ini terdapat 27 isolat bakteri yang diuji methyl red. Terdapat 27 isolat bakteri yang hasilnya positif ditunjukkan dengan perubahan menjadi warna merah. Menurut Chatim dan Surahman (2002) methyl red digunakan sebagai indikator untuk memperlihatkan penurunan $\mathrm{pH}$ karena terbentuknya asam sebagai akibat fermentasi pada medium biakan yang mengandung glukosa, yang di dalamnya bakteri telah tumbuh selama 2-4 hari. Bakteri yang tumbuh dan membentuk banyak asam organik adalah E. coli sekaligus menunjukkan hasil positif terhadap methyl red. 
Warna merah akan terlihat jika $\mathrm{pH}$ perbenihan di bawah 5. Hasil penelitian ini dapat dilihat pada
Gambar 4 yang menunjukkan perubahan warna menjadi merah muda.
A

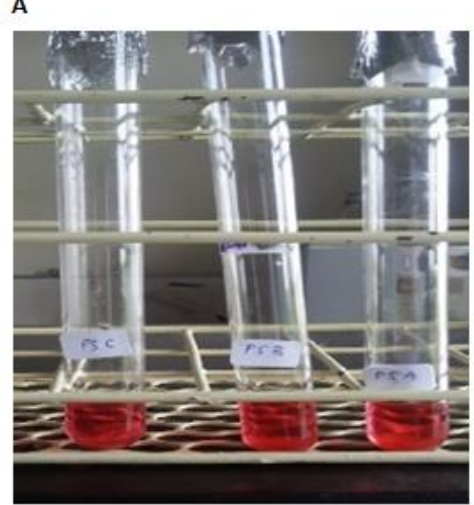

B

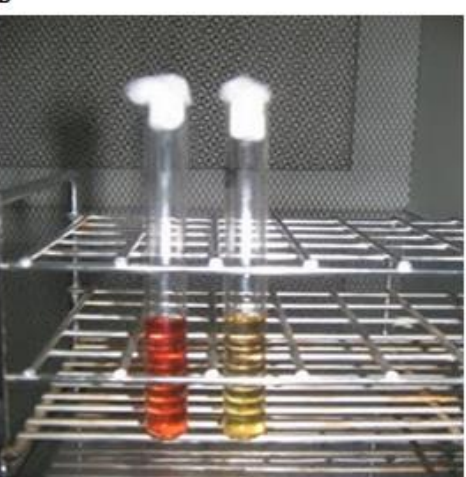

Gambar 4. Gambar A menunjukkan hasil uji Methyl red positif sampel urin pada pasien ISK. Gambar B Hasil uji methyl red jika terjadi perubahan warna (+) dan tidak berwarna (-).

4. Uji VP (Voges Proskauer)

Pada penelitian ini terdapat 27 isolat bakteri yang diuji VP. Terdapat 27 isolat bakteri hasilnya negatif yang ditunjukan tidak adanya perubahan warna. E.coli tidak mampu membentuk asetoin. Asetoin dideteksi dengan ditambahkan $3 \mathrm{~mL}$ larutan naftol dan $1 \mathrm{ml} \mathrm{KOH}$ kemudian diaduk. Jika terbentuk warna merah menunjukkan terbentuknya asetoin (Chatim dan Surahman, 2002). Volk \& Wheeler (1989) menambahkan kehadiran asetoin menunjukkan adanya fermentasi 2,3 butilen glikol yang negatif untuk E.coli (Gambar 5).

5. Uji simons sitrat

Uji sitrat merupakan uji yang digunakan untuk melihat kemampuan mikroorganisme menggunakan sitrat sebagai satusatunya sumber karbon (Duncan, 2005). Uji sitrat dilakukan dengan inokulasi mikroorganisme ke dalam media sintetis organik Simons Citrate broth apabila natrium sitrat adalah satu-satunya sumber karbon dan energi. Bromothymol blue digunakan sebagai indikator saat asam sitrat dimetabolisme, menghasilkan 
karbondioksida

yang

menggabungkan natrium dengan air

untuk membentuk natrium karbonat

yang merupakan produk alkalin yang menghasilkan perubahan warna dari hijau menjadi biru dan hal ini menunjukkan tes tersebut positif (Sridhar, 2006) (Gambar 6).
A

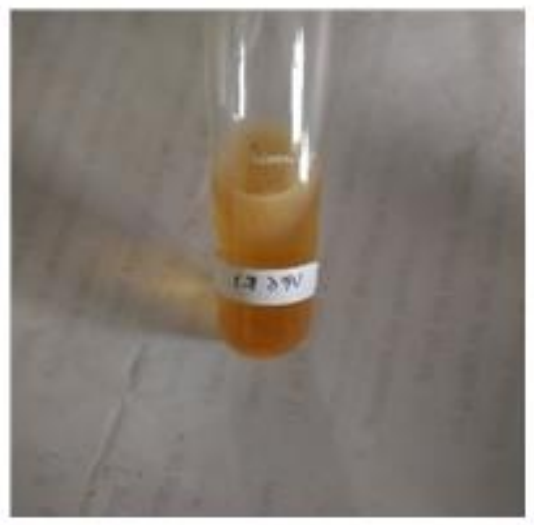

B

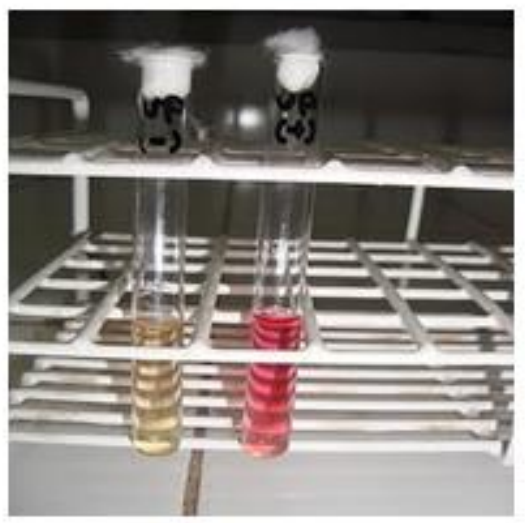

Gambar 5. Gambar A menunjukkan bahwa hasil uji VP negatif sampel urin pada pasien ISK. Gambar B menunjukkan hasil uji VP jika bewarna merah (+) dan tidak berwarna (-).

A

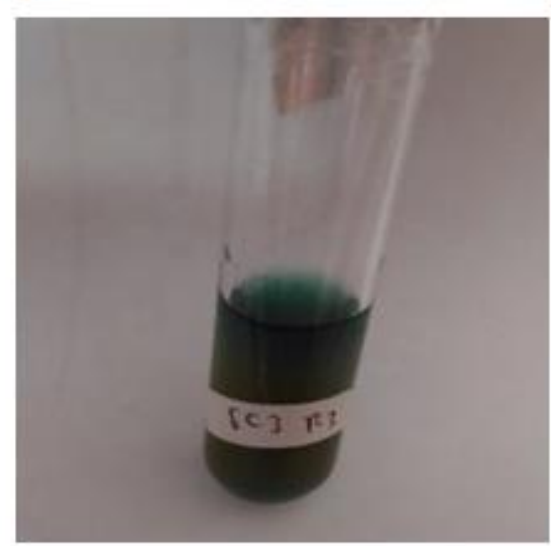

B

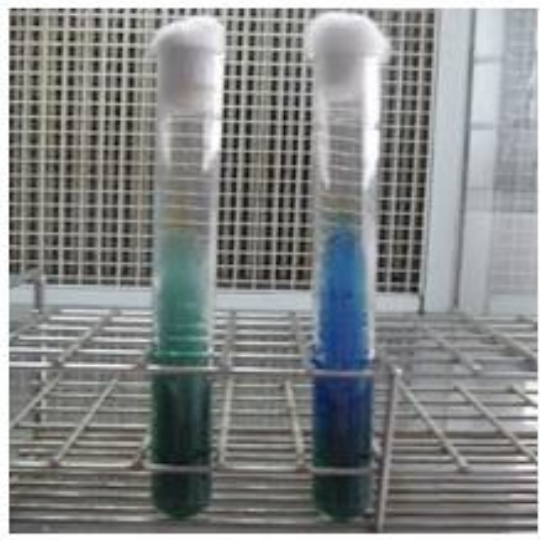

Gambar 6. Gambar A menunjukkan hasil uji sitrat negatif pada sampel urin pasien ISK, Gambar B menunjukkan hasil uji sitrat jika bewarna biru (+) dan tidak berubah tetap hijau (-). 
Duapuluh tujuh isolat pada penelitian ini menunjukkan hasil negatif terhadap uji simmons sitrat. Menurut Chatim dan Surahman (2002), E. coli tidak mampu menggunakan sitrat sebagai sumber karbon sehingga uji sitrat menunjukkan hasil yang negatif. Sitrat tidak mampu menembus dinding sel bakteri $E$. coli dan E. coli juga tidak mampu menghasilkan enzim permiase (Gambar 6).

Tabel 1. Rentang sensitivitas antibiotik berdasarkan CLSI

\begin{tabular}{ccccc}
\hline \multirow{2}{*}{ Antibiotik } & Konsentrasi & \multicolumn{3}{c}{ Diameter ZonaHambat (mm) } \\
\cline { 3 - 5 } & Cakram & $\mathrm{R}$ & $\mathrm{I}$ & $\mathrm{S}$ \\
\hline Cefixime & $5 \mu \mathrm{g}$ & $<15$ & $16-18$ & $>19$ \\
Asam pipemidat & $50 \mu \mathrm{g}$ & $<11$ & $15-22$ & $>23$ \\
\hline Keterangan: $\mathrm{R}=$ Resisten; I $=$ Intermediet; $S=$ Sensitif & &
\end{tabular}

Tabel 2. Hasil uji identifikasi bakteri

\begin{tabular}{|c|c|c|c|c|c|}
\hline sampel & Pewarnaan Gram & Uji Indol & Uji methyl red & Uji VP & Uji sitrat \\
\hline 1 & - & + & + & - & - \\
\hline 2 & - & + & + & - & - \\
\hline 3 & - & + & + & - & - \\
\hline 4 & - & + & + & - & - \\
\hline 5 & - & + & + & - & - \\
\hline 6 & - & + & + & - & - \\
\hline 7 & - & + & + & - & - \\
\hline 8 & - & + & + & - & - \\
\hline 9 & - & + & + & - & - \\
\hline
\end{tabular}

Uji Kepekaan Bakteri terhadap Antibiotik

Resistensi primer merupakan resistensi yang menjadi sifat alami mikroorganisme. Hal ini dapat disebabkan oleh adanya enzim pengurai antibiotik pada mikroorganisme sehingga secara alami mikroorganisme dapat menguraikan antibiotik. Contohnya resistensi $E$. coli terhadap penisillin disebabkan oleh kemampuan bakteri menghasilkan enzim $\beta$ laktamase yang disandi oleh gen dalam plasmid faktor R. Faktor R termasuk kelas plasmid yang membawa gen untuk resisten terhadap satu atau lebih obat antibiotika sering mengontrol pembentukan enzim yang dapat 
menghancurkan obat (Krisnaningsih et al., 2005).

Antibiotik yang digunakan dalam penelitian ini adalah asam pipemidat dan cefixime yang berupa kapsul yang kemudian dibentuk suspensi. Masing-masing antibiotik tersebut merupakan antibiotik yang sering diresepkan di RSUD Prof. Dr. Margono Soekardjo Purwokerto, Jawa Tengah, untuk mengobati penderita ISK. Menurut Kemenkes RI (2011) meluasnya penggunakan antibiotik yang tidak tepat menimbulkan berbagai permasalahan dan merupakan ancaman global bagi kesehatan, terutama resistensi bakteri terhadap antibiotik. Untuk itu diperlukan penggunaan antibiotik secara rasional untuk mencegah penyebaran bakteri yang resisten terhadap antibiotik.

Antibiotik asam pipemidat sebanyak $5 \mu \mathrm{L}$ dan cefixime sebanyak
$5 \mu \mathrm{L}$ diteteskan di atas kertas cakram dan diinkubasi selama 24 jam pada suhu $37^{\circ} \mathrm{C}$. Setelah diinkubasi selama 24 jam terdapat zona hambat berupa zona bening di sekitar kertas cakram menandakan adanya aktivitas antibiotik untuk bekerja secara bakterisid atau mampu membunuh bakteri dengan menimbulkan area jernih pada media MHA maupun bakteriostatik atau mampu menghambat pertumbuhan bakteri dengan menimbulkan area jernih. Zona hambat yang terbentuk pada medium MHA diukur dengan jangka sorong dan hasilnya dibandingkan dengan tabel standar CLSI (Clinical and Laboratory Standards Institute) untuk menentukan hasil isolat bakteri tersebut sensitif, intermediet, atau resisten (Said, 2013).

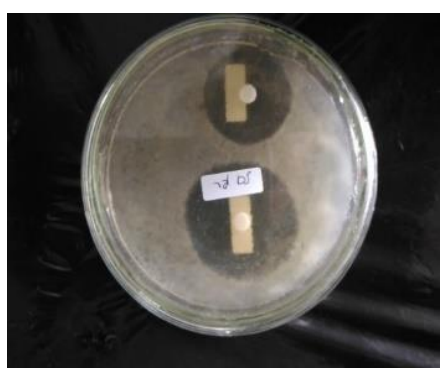

Gambar 7. Hasil uji sensitivitas antibiotik cefixime dan asam pipemidat terhadap pasien penderita ISK. 
Tabel 3. hasil uji sensitivitas bakteri terhadap antibiotik asam pipemidat

\begin{tabular}{clllrl}
\hline \multirow{2}{*}{ Sampel } & \multicolumn{4}{c}{ Diameter Zona Hambat $(\mathrm{mm})$} & \multirow{2}{*}{ Ket } \\
\cline { 2 - 5 } & $\mathrm{R} 1$ & $\mathrm{R} 2$ & $\mathrm{R} 3$ & Rata-rata & \\
\hline 1 & 22 & 22,5 & 22,8 & 22,4 & $\mathrm{I}$ \\
2 & 21,2 & 21,6 & 22 & 21,6 & $\mathrm{I}$ \\
3 & 20 & 24,9 & 38,2 & 27,7 & $\mathrm{~S}$ \\
4 & 24,6 & 22,3 & 23,6 & 23,4 & $\mathrm{~S}$ \\
5 & 24,5 & 24 & 23,7 & 24 & $\mathrm{~S}$ \\
6 & 26,7 & 26,5 & 27,4 & 26,8 & $\mathrm{~S}$ \\
7 & 22,4 & 21,8 & 21,5 & 21,9 & $\mathrm{I}$ \\
8 & 26,1 & 22,2 & 25,5 & 24,6 & $\mathrm{~S}$ \\
9 & 26,3 & 30,1 & 33 & 29,8 & $\mathrm{~S}$ \\
\hline
\end{tabular}

Tabel 4. Hasil uji sensitivitas bakteri terhadap antibiotik cefixime

\begin{tabular}{clcccc}
\hline \multirow{2}{*}{ Sampel } & \multicolumn{4}{c}{ Diameter Zona Hambat (mm) } & \multirow{2}{*}{ Ket } \\
\cline { 2 - 5 } & $\mathbf{R 1}$ & $\mathbf{R 2}$ & $\mathbf{R 3}$ & Rata-rata & \\
\hline 1 & 17,3 & 17 & 18,6 & 17,6 & $\mathrm{I}$ \\
2 & 20,2 & 18,6 & 18,5 & 19,1 & $\mathrm{~S}$ \\
3 & 24 & 24,3 & 23,6 & 23,9 & $\mathrm{~S}$ \\
4 & 28 & 27,5 & 27,2 & 27,5 & $\mathrm{~S}$ \\
5 & 29 & 28,6 & 27,4 & 28,3 & $\mathrm{~S}$ \\
6 & 18,5 & 17,8 & 17,2 & 17,8 & $\mathrm{I}$ \\
7 & 18,5 & 17,6 & 20 & 18,7 & $\mathrm{I}$ \\
8 & 25,3 & 23,3 & 26,1 & 24,9 & $\mathrm{~S}$ \\
9 & 19,6 & 18,3 & 18,6 & 18,8 & $\mathrm{I}$ \\
\hline
\end{tabular}

Dari 27 isolat bakteri yang sudah melalui uji sensitivitas terhadap antibiotik asam pipemidat dan cefixime, yang merupakan E. coli mempunyai zona hambat yang berbeda-beda pada setiap uji yang menandakan bahwa setiap bakteri mempunyai ketahanan yang berbeda terhadap antibiotik yang diberikan. Berdasarkan hasil uji sensitivitas isolat bakteri pada Tabel 1 menunjukkan bahwa isolat bakteri $E$. coli $66,7 \%$ sensitif terhadap asam pipemidat dan $33,3 \%$ intermediet terhadap asam pipemidat. Hal ini menunjukkan bahwa antibiotik asam pipemidat efektif diberikan kepada pasien ISK yang menjalani pengobatan di RSUD Prof. Dr. Margono Soekardjo Purwokerto.

Berdasarkan penelitian pada antibiotik cefixime, hasil uji sensitivitas isolat bakteri menunjukan bahwa 
isolat bakteri $E$. Coli $55,6 \%$ sensitif dan $44,4 \%$ bernilai intermediet. Cefixime adalah sefalosporin generasi ke-3 yang digunakan dalam pengobatan bakteri penyebab ISK. Cefixime aktif terhadap spektrum yang sangat luas dari bakteri seperti E. coli, Staphylococcus aureus, Streptococcus pneumoniae, Streptococcus pyogenes, Hemophilus influenzae, Salmonella, shigella, dan Neisseria gonorrhoeae. Dalam penelitian Chaudhary et al. (2015), cefixime diberikan dua kali sehari selama 7-10 hari dalam pengobatan 65 pasien yang menderita ISK. Tidak hanya studi mengevaluasi kemanjuran cefixime dalam pengobatan ISK tetapi juga menunjukkan keamanannya dan tolerabilitas di mayoritas pasien sehingga dapat digunakan sebagai obat alternatif untuk pengobatan ISK.

Hasil uji sensitivitas bakteri pada penelitian ini menunjukkan bahwa masih sensitif terhadap antibiotik asam pipemidat dan cefixime terhadap bakteri yang diduga $E$. coli. Pada penelitian yang dilakukan oleh Sumolang et al. (2013) di RSUP Prof. Dr. R. D. Kandou Manado, bakteri penyebab ISK terbesar adalah $E$. coli. Menurut Kumala et al. (2009), fosfomisin dan sefepim menunjukkan aktivitas penghambatan pertumbuhan yang baik juga terhadap semua bakteri Gram negatif. Antibiotik fosfomisin dan sefepim paling efektif terhadap semua bakteri penyebab ISK dalam penelitian ini. Sehingga diperkirakan fosfomisin dan sefepim mampu menghasilkan respon klinik yang baik, tentunya disesuaikan dengan indikasi penggunaannya.

\section{Kesimpulan}

1. Hasil identifikasi dari 9 sampel urin yang didiagnosa menderita penyakit infeksi saluran kemih (ISK) oleh dokter di RSUD Prof. Dr. Margono Soekardjo Purwokerto, didapatkan hasil uji isolat sampel menunjukkan bahwa bakteri penyebab ISK pada penelitian ini diduga adalah E. coli.

2. Hasil uji sensitivitas bakteri terhadap antibiotik menunjukkan bahwa bakteri yang diduga E. coli menunjukkan bahwa terhadap antibiotik asam pipemidat dengan rata-rata zona hambat sebesar $66,7 \%$, masih sensitif dan antibiotik cefixime nilai zona hambat dengan rata-rata sebesar $55,6 \%$ sensitif terhadap E. coli. 


\section{Daftar Pustaka}

Arisman. 2009. Buku Ajar Ilmu Gizi Keracunan Makanan. Jakarta: EGC.

Chaudhary, K.M., Pandey. G., Godar, M., Gautam, R., Gurung, S. 2015. Efficacy of cefixime in the treatment of urinary tract infection. World Journal of Pharmacy and Pharmaceutical Sciences, 4(4):987-994.

Chatim, A., Surahman, S. 2002. Penuntun Praktikum

Mikrobiologi Kedokteran. Jakarta: Binarupa Aksara.

Duncan, F. 2005. MBC 1000L Applied Microbiology Laboratory Manual. 4th Ed. New York: The McGraw-Hill Companies.

Guntur, A.H., Sepsis. 2007. Buku Ajar Ilmu Penyakit Dalam. Sudoyo, A.W., Setiyohadi, B., Alwi, I. (Editor). Jakarta: Pusat Penerbit IImu Penyakit Dalam, FK UI.

Irianto, K. 2006, Mikrobiologi: Menguak Dunia Mikroorganismel Jilid 2. Bandung: CV. Yrama Widya.

Kumala, S., Raisa, N., Rahayu. L., Kirana. S. 2009. Uji Kepekaan Bakteri Yang Diisolasi Dari Urin Penderitalnfeksi Saluran Kemih (Isk) Terhadap Beberapa Antibiotika Pada Periode MaretJuni 2008. Majalah IImu Kefarmasian, 6(2):45-55.

Kemenkes RI. 2011. Standar Antropometri Penilaian Status Gizi Anak. Jakarta: Direktorat Bina Gizi.
Krisnaningsih, F.M., Asmra, W., Wibowo, M.H. 2005. Uji sensitivitas isolat Escherichia coli pada ayam terhadap beberapa jenis antibiotik. J Sain Vet, I:13-18.

Sahm, D.F., Thornsberry, C., Mayfield, D.C. 2001. Multidrug-resistant urinary tract isolates of Eschericia coli: prevalence and patient demographics in the united states. Antimicrobial Agent and Chemotherapy, 45:1402-1406.

Said, A. 2013. Analisis Pola Kuman dan Hasil Kepekaan Anti mikroba pada Otitis media Supuratif Kronik di RSUP Dr. Wahidin Sudirohusododan RS Daya Makasar tahun 2013. Makasar: Fakultas Kedokteran Universitas Hasadnuddin Makasar.

Seta, I.S., Hertanti, I.L., Rizka. 2015. Pola kepekaan bakteri penyebab infeksi saluran kemih pada anak terhadap antimikroba. Majalah Kedokteran Sriwijaya, 47(2):8590.

Sridhar, R.P.N. 2006. IMViC reaction. JJMMC.

Sotelo, T., Westney, O.L. 2003. Recurent urinary tract infection in women. Curr Women's Health Rep, 3(4):313-318.

Sumolang, S.A., Puroto'o, J., Soeliongan, S. 2013. Pola bakteri pada penderita infeksi saluran kemih di blu RSUP Prof. Dr. R. D. Kandou Manado. Jurnal eBiomedik (eBM),1(1):597-601. 
Tessy, A., Ardayo, Suwanto. 2004. Infeksi Saluran Kemih dalam Buku Ajar IImu Penyakit Dalam. Jilid 3. Edisi 3. Jakarta: Balai Penerbit FKUI.
Volk, W.A., Wheeler, M.F. 1990. Mikrobiologi Dasar. Jilid 2 Edisi Kelima. Jakarta: Erlangga. 